\title{
Residência Médica
}

A Federação Brasileira das Sociedades de Ginecologia e Obstetrícia (FEBRASGO), preocupada com a qualidade do especialista em formação e para que ele seja cada vez mais melhor habilitado está trabalhando, desde 1995, em diferentes frentes.

A primeira foi arrumar a casa, organizando e elaborando o que pensamos seja o melhor para os colegas em formação, os conteúdos e a estrutura considerados mínimos que todo o serviço de formação de especialistas na área deveria possuir. Isto já está publicado no Manual do Regimento da Residência Médica da FEBRASGO. Para alcançar estas metas, contamos sempre com o apoio e a efetiva colaboração da Secretaria da Comissão Nacional de Residência Médica (CNRM) do Ministério de Educação e Cultura (MEC), de suas Comissões Estaduais e das Federadas da FEBRASGO.

A segunda, foi trabalhar, em Brasília, com a CNRM, para alcançar denominadores que satisfizessem ambas as partes. Por diversas vezes, colaboramos com a referida Comissão como consultores na Avaliação de Programas da Especialidade no Brasil.

Não obstante, pensando no futuro, ampliamos nosso campo de atuação e, hoje, depois de três anos e meio de reuniões e de discussões, estabelecemos o que deva se constituir, para os países da Confederação das Sociedades de Ginecologia e de Obstetrícia do Mercosul (COSOGO-Mercosul), Argentina, Paraguai e Uruguai, em um Programa de Residência Médica mínimo para a formação de especialistas que irão atender nossos povos.

Muitas Federadas, já constituíram Comissões que reúnem os Programas de Residência Médica de seu estado, criando a oportunidade para que discutam suas dificuldades e os conteúdos que julgam mais convenientes para suas realidades, sempre apoiados pelo representante da Comissão Estadual de Residência Médica do MEC. A Comissão Estatutária de Residência Médica da FEBRASGO está pronta para colaborar com as Federadas, que assim desejarem, para o estabelecimento destas Comissões que julgamos ser a forma e o fórum mais adequados para discussões e para o estabelecimento de novas realidades e que representarão um crescimento efetivo de todos os envolvidos na formação do especialista. Precisamos lutar e estimular para que todas as Federadas da FEBRASGO tenham suas Comissões Estaduais de Residência Médica. Por isto estamos aqui.

\section{A Diretoria}

